\title{
BEAUTY AND UGLINESS IN THE POETRY COLLECTION MAULİDAL- DIBA' I BY ABDURRAHMAN AL-DIBA'I: A SIEGELIAN AESTHETICS PERSPECTIVE
}

Fadlil Munawwar Manshur

Universitas Gadjah Mada, Indonesia.

Email: fadlildsugm@gmail.com

\author{
Article History: Received on $28^{\text {th }}$ January 2020, Revised on $15^{\text {th }}$ April 2020, Published on $15^{\text {th }}$ June 2020
}

\begin{abstract}
Purpose: The formal objective of this study is to explore the beauty and ugliness contained within the poetry collection Maulìd Al-Diba'i, an Arabic-language text that conveys messages of beauty and ugliness in its verses. The material of this study is the poetry collection Maulīd Al-Diba'i, which was written by Imam Wajihuddin 'Abdur Rahman bin Muhammad bin 'Umar bin 'Ali bin Yusuf bin Ahmad bin 'Umar ad-Diba'ieasy-Syaibani al-Yamani az-Zabidiasy-Syafi'i (henceforth Abdur Rahman Al-Diba'i).
\end{abstract}

Methodology: The current research is descriptive that explains the crux of poetry. For this purpose the poetry collection Maulīd Al-Diba' I was used and analysed. To achieve the objective analytical method was used.

.Main Findings: Based on the analysis, it may be concluded that the poetry collection Maulid Al-Diba'i is a work of Arabic-language Islamic literature that was influenced by the verses of the Qur'an and their beauty. The verses of Maulid Al-Diba'i are conveyed through the language of prayers, hopes, and blessings. These prayers, hopes, and blessings contain within them their beauty, both at the surface and below it. The poet, Abdurrahman Al-Diba'i, readily conveys his prayers, hopes, and blessings by briefly retelling the story of the Prophet Muhammad's travels to spread Islam throughout the Arabian Peninsula.

Implications/Applications: This article applies the theory of aesthetic realism, which contains within it two key concepts: physical beauty and divine beauty. Physical beauty is related to the perceptions of the senses, and is cognitive, cultural, and natural, whereas divine beauty is perceived through the mind and promotes awareness and mental experience.

Novelty/Originality of this study: This research will uncover the facts that on what basis, in the poetry collection Maulid Al-Diba'i, is there a dominant message of beauty that is expressed explicitly and opposed with a message of ugliness that is expressed implicitly. It will also add to literature explaining that the text Maulid Al-Diba'i may be understood as a tool for satisfying the spiritual demands of readers and enabling them to contemplate their religion.

Keywords: Maulìd Al-Diba'I, Aesthetic Realism, Beauty, Ugliness.

\section{INTRODUCTION}

The text Maulìd Al-Diba'i, as an Arabic-language Islamic literary text, has a beauty and rhetoric that cannot be separated from the influence of the Qur'an. The Qur'an is not written in the prose commonly used by Arabs, nor in poetry; nonetheless, it created a paradigm shift within the language and rhetoric of Islamic Arabic literature. This paradigm shift can be seen, for example, in how the Qur' and reconstructed the traditional genres and conventions of pre-Islamic Arabs. The Qur'an refers to itself as a Kitab, which Ebrahim Moosa translates as 'master text', and has provided a standard for literary and rhetoric excellence. Thaha Hussein (1889-1973) emphasizes the aesthetic and literary excellence of the Qur'an, written in what is termed $i^{\prime} j \bar{a} z$ (the perfect language); neither poetry nor prose, the Qur'an is innovative in its style and aesthetic (jadīdan fi uslübihi) (Bin Tyeer, 2016). Expressing the beauty of the world and its beings are one key purpose of the beauty of the Qur'an. In the seventh verse of Sura As-Sajdah, God explicitly refers to this concept. "Who perfected everything He created and began the creation of man from clay. "

The word "perfect" (Arabic: al-Husn) in this verse is the most comprehensive term available in Arabic to express beauty. In this verse, creation and beauty are bound (Ghehi, 2017). As such the Qur' anis truly a master text, offering a comprehensive concept of beauty that has been referenced by Arabic-language Islamic literature since the death of the Prophet Muhammad. The beauty of the Qur'an can be seen, for example, in its verses that reference history, law, and salvation, which may be characterized at times as narrative, apocalyptic, or even poetic. As such, many works of Arabic literature - including Maulīd Al-Diba'i-have sought to convert beauty and the nobleness of the Qur'an, as written in the original Arabic (Feener, 2014). This is why, according to Adūnis, one could not separate the Qur'an and Arabic at any level. The revelation of the Qur'an created intellectual, artistic, and religious paradigm shifts, as well as transformations in literature and culture (Bin Tyeer, 2016). The Arab people and their Islamic religion thus became important elements in the development of cultures around the world, influenced not only by their ethnic pride and ability as conquerors but also their passion for embracing new ideas. Over time, Arabic became a universal language, driving the emergence of Arabic art, science, and writers (Goldschmidt Jr \& Davidson, 2006) and ultimately works of Islamic literature inspired by the Qur'an (including Qasidah al-Burdah, Maulìd Al-Barzanjy, and Maulīd Al-Diba'i). 
All of these Arabic-language works of Islamic literature contain within them textuality, intertextuality, and extratextuality, which imbue them with religious significance. To understand how Muslims produce religious meaning, particularly how they interpret the Qur'an, it is necessary to understand which primary texts are popular among them. How Arabic-language works of Islamic literature are read influenced social practices, laws, and state administration in Muslim countries for centuries before the doors of ijtihād and hermeneutic criticism were closed between the fourth and tenth century CE. As such, a textual approach to understanding Islamic discourse, including examination of textual, intertextual, and extratextual elements, can be used to understand religious works (Barlas, 2002; 2008) such as Qasïdah al-Burdah, Maulìd Barzanji, and Maulìd Al-Diba'i. In the interest of limiting the scope of this research, this article will examine only the textual elements of Maulīd Al-Diba'i.

According to Abu Zayd, the Qur'an has led to the creation of new cultures through its linguistic excellence and stylistic uniqueness, through which it has challenged the traditional distinctions between philosophy and literature, science and politics, ethics, and aesthetics, and genre and form. Methodologically, the Qur'an has provided an episteme for conventional approaches (al-muqārabātal-ma'rifiyya). In other words, the cultures that have emerged around the Qur'an may be seen as what Hans-Georg Gadamer terms application. The Qur' anis, not a passive text that simply awaits clarification and explication, but rather an active text that is applied dynamically and practically. The Qur' anis a highly interactive text, with significant rhetoric effectiveness (Bin Tyeer, 2016). In this context, Maulīd Al-Diba'i-a work of Arabic-language Islamic literature - has functioned to guide the spirituality of communities and teach them how to overcome worldly problems. As such, to borrow from UmbertoEco, by borrowing from the approaches to problemsolving of a specific era we can understand the aesthetic sensibilities and awareness of that era (Alami, 2011; Gomez \& Gomez, 2018). In other words, by understanding the problems of Arabic-language Islamic literature, a reader can understand the aesthetic sensibilities and awareness underlying it.

The Qur'an produced not only new cultures but also new Muslims. These new Muslims required an aesthetic that could satisfy their spiritual demands and enable them to contemplate and understand their religion. This aesthetic is also necessary to reinforce their shared ideology and social structure, as well as to stress the importance of maintaining an Abrahamic monotheism. From the perspective of aesthetics, art functions to strengthen humans' awareness of God and their positions (Ali, 1997, 2002). As such, the text Maulid Al-Diba'i may be understood as a tool for satisfying the spiritual demands of readers and enabling them to contemplate their religion.

Maulid Al-Diba'i is an Arabic-language poetry collection with a beauty that is inspired and guided by the Qur'an. Historically, the birth of this text was inspired and influenced by the Qur'an, and as such Maulīd Al-Diba'i may be identified as an applicative text because it is read and practised by its readers-in this case, the Indonesian people. Because of its artistic dynamicity and unique style, the Qur'an has been described as not imitating life (hikäyatal-hayāt), but rather offering life. While art is understood as imitation (mimesis) of life, this is not true for the Qur'an; it is a dynamic text that offers life and inspires are and literature. The influence of the Qur' a reaches beyond stylistics, structure, formula, and idiom. Its influence is thematic, conceptual, and categorical. It is the influence of the Qur'an that explains how literature becomes ethical or philosophical. As such, the Qur'an offers a new paradigm that Adnus identifies as the 'horizon for other writing' (khāssiyya tafta'uli-l-kitābati ufuqan ākhar) (Bin Tyeer, 2016), including Arabic-language poems with Islamic themes such as those in Maulid Al-Diba'i.

Maulid Al-Diba'i is an Arabic-language literary text that has found popularity in several Muslim-majority countries, including Indonesia. It may be identified as popular in Indonesia as the text is widely read by individuals and groups throughout the country. Maulìd Al-Diba'i may also be termed literature for its contents, which are primarily the poet's prayers, hopes, and blessings for the Prophet Muhammad. In Indonesia, two Arabic-language literary texts other than Maulìd Al-Diba'i are well-known among readers in pesantren (Islamic boarding schools), namely Qasidah al-Burdah and Maulīd Al-Barjanjy. Muslims who are not used to reading the Qur'an as part of their worship view reading the prayers, hopes, and blessings contained within MaulïdAl-Diba'i as part of their worship. In such a situation, the revelations of the Qur'an may be understood as involving two different levels of discourse. First is the level of concrete or worldly meaning, which involves the ability of the common people to understand and follow the teachings of Islam. Second is the mental level, which involves the deepest and most essential meaning of the text (Whittingham, 2007; Alahoul, Azizan, \& Alwi, 2016). As such, reading texts such as Maulīd Al-Diba'i as a complement to the Qur'an can enable people to better understand and practice the teachings of Islam in their everyday lives.

From a conceptual/theoretical perspective, Maulìd Al-Diba'i contains prayers, hopes, and blessings for the Prophet Muhammad as the person chosen by God to be an example for all. The Prophet Muhammad is also viewed as a Muslim leader who always taught peace to his followers to ensure that harmony was maintained. Islam is a religion of peace, but it has never rejected the possibility of war, and the Qur'an permits self-protection. Similarly, there are records of the Prophet Muhammad taking up arms. However, the wars that are approved by Islam and its texts are defensive, fought when the religion and its adherents are attacked. Islam's primacy lies in its emphasis on peace. J. Patout Burns, a scholar of comparative religion, emphasizes that it is not problematic for Islam to restrain its adherents to non-violent means. "All religions can result in violence or non-violence", emphasized the non-violence advocate Professor Muhammad Abu-Nimer. Another scholar, K. G. Saiyidain, underscored that non-violence is a core tenet of Islam and that while Muslims could consider war, non-violent approaches are preferred $(\mathrm{Pal}, 2011)$. As such, the poetry collection Maulìd Al- 
Diba'i conveys the poet's message through prayers, hopes, and blessings for the Prophet Muhammad, using words of beauty and peace.

From a practical/material perspective, Maulìd Al-Diba'i contains within it elements of harmony that convey a beautiful melody. This harmonious melody has a positive effect on the mind and contributes to the formation of etiquette and propriety. This melody can also function to calm those who are angry or soften a hard heart. In short, its melodyrepresented as a beautiful voice — can bring peace to the human heart and mind (Alami, 2011). It will bring joy and peace to the reader, especially when the text is read and sung as a salutation to God. As such, Maulīd Al-Diba'i-as a text that will have its beauty enhanced by being sung by a person with a melodious voice — can thus calm the hearts and minds of readers and listeners. Similarly, doctors have written that a melodious voice can enter the body and circulate through the veins, cleansing the blood, relaxing the heart, mobilizing the limbs, and bringing joy (Alami, 2011). For this study, however, Maulìd Al-Diba'iis not discussed in terms of melody (rhyme and rhythm); such research would require extensive field studies in pesantren that utilize the text and give it a voice in varied ways.

Based on the background above, the research problem may be identified as follows: Why, in the poetry collection Maulid Al-Diba'i, is there a dominant message of beauty that is expressed explicitly and opposed with a message of ugliness that is expressed implicitly? The collection Maulìd Al-Diba'i has inspired many to write literary works in the Salawat (salutation) genre to explicitly express specific aesthetic understandings, as well as to reveal implicitly the ugliness of the human behaviours that lie behind this beauty. The collection Maulid Al-Diba'i has been widely read in the Muslim world, particularly in Indonesia, as an expression of a deep longing for the Prophet Muhammad. Persons living in the modern-day feel a desire to meet with the Prophet. As a physical meeting is impossible, they seek an alternative: reading Maulīd Al-Diba'i as a means of praying for, expressing their hopes to, and blessing the Prophet Muhammad.

\section{Research gap and objectives of the studies}

Given the above studies, it could understand that explore the beauty and ugliness contained within the poetry collection Maulīd Al-Diba'i, (which is an Arabic-language text that conveys messages of beauty and ugliness in its verses) has not been done yet.

Therefore, the purpose of this study is the poetry collection Maulīd Al-Diba'i, which was written by Imam Wajihuddin 'Abdur Rahman bin Muhammad bin 'Umar bin 'Ali bin Yusuf bin Ahmad bin 'Umar ad-Diba'ieasy-Syaibani al-Yamani az-Zabidiasy-Syafi'i (henceforth Abdur Rahman Al-Diba'i). The title of the collection, Maulìd Al-Diba'i, is thus derived from the name of its writer. This collection contains within its eight lengthy poems (kasidah) that are written in beautiful Arabic. For this study, the fourth of these poems has been chosen to owe to its popularity in Indonesian society.

\section{LITERATURE REVIEW}

Research using an aesthetic realism perspective was conducted by Perey (1976) under the title "The Aesthetic Realism of Eli Siegel as a Teaching Method in Anthropology", which was published in the Council on Anthropology and Education Quarterly, 7(4): 46-48. In his study, Perey examined Siegel's view that: (i) every person should attempt to express the opposition within them, (ii) every person should honour themselves and view the world as good and beautiful, (iii) there is a tendency for people to believe that they will act as themselves, with minimal outside influence, and (iv) all beauty comes from opposition, and the opposition is what we seek within ourselves.

Following the formal object of this study, namely beauty and ugliness in the poetry collection Maulìd Al-Diba'i, the theory most appropriate for this study is aesthetic realism. This theory is appropriate given the fact that MaulidAl-Diba'i contains within its beauty and ugliness, which is expressed by the poet through beautiful verse. Although the text of Maulid Al-Diba'i may be categorized as fictional/artistic, having been written by an ulama (Islamic scholar) named Abdur-Rahman Al-Diba'i, its contents are centred around the aesthetics of struggle, namely the journey undertaken by the Prophet Muhammad while spreading Islam. As Aristotle argued in his Poetics, art functions to imitate reality; it may be assumed that reality and mimetic elements of aesthetic products such as manuscripts, illustrations, and performances can be recognized over time (Slethaug, 2007).

In Islam, as argued by Gonzalez (2001), the concept of aesthetics includes two levels of beauty: physical beauty and divine beauty, respectively perceived through the senses and the minds. The first level of beauty deals with sensory perceptions and perceptual capacities that support mental awareness and experience. The second, meanwhile, is akin to artistic beauty, both philosophical and metaphysical, which is manifested through the physical work itself. In Islam, the theoretical and artistic aesthetic is united in concepts that are linked to religious metaphysics and understandings of the world and humanity. Common in Islamic aesthetics is understanding poetry as an important art form in Arabic culture. Generally, poetry contains within it a syllogism that urges audiences to act, which draws the emotions and the imagination (Groff \& Leaman, 2007). As such, it may be surmised that the writer of Maulid Al-Diba'i is urging his audience (readers) to do good deeds, to praise and honour the Prophet Muhammad, and to hone their understanding of the beauty and ugliness of the world.

Beauty is an integral part of aesthetics and is involved not only in art and literature but also in worldly phenomena and human behaviour. As a text of Salawat, the poetry collection Maulìd Al-Diba'i has power in its words and its messages 
about human and worldly problems. In this, we may refer to the views of Horace (65-68 BCE) regarding art and poetry. According to Horace, the beauty of poetry lies not only in the poetry itself but also in the poet's ability to combine beauty (dulce) and utility (utile) (Susanto, 2015). Poems enable us to appreciate ourselves and our world in new ways. Horace argues that poetry is usually written to examine the self (Brink, 2011). The German philosopher Immanuel Kant (17241804) also discussed aesthetics within the context of bringing joy to readers (Hegel, 1998; Balushi, Bulushi, \& AlRiyami, 2018; Citraningtyas, 2017). Aesthetics deals with what we sense, perceive, and taste, our understandings, and experiences. It involves our sight, hearing, and capacity of human beings, and seeks to invoke particular responses to various objects and experiences (Syafiie, 1998).

In this, the poetry collection Maulid Al-Diba'i may be understood simultaneously as a literary and religious work, one that serves to calm the reader and further the development of Arabic-language Islamic literature. From an esthetics perspective, Maulìd Al-Diba'i may also be viewed as a literary work that emphasizes the feelings, experiences, and perceptions of readers around the Muslim world, including in Indonesia.

This study relies on the theory of aesthetic realism first presented by Eli Siegel. According to Siegel, aesthetic realism explores the link between logic, emotion, and continuity (Siegel, 1981, 1997). This can be seen in works of art and design that are deemed pleasing, as understandable through an appropriate mindset (Kartika \& Perwira, 2004; O'Mahony, 2018). Aesthetic realism argues that human beings' greatest goal in life is to present reality in an aesthetic form that can be received and appreciated by others. Aesthetic realism cannot force people to like reality; however, it nonetheless hopes that people will find pleasure in reality and do their best to enjoy it. Aesthetic realism views the world neatly and orderly (Siegel, 1981), a fact manifested in prose and poetry through depictions of beauty and ugliness.

From an aesthetic realism perspective, Maulīd Al-Diba'i-as a beautiful work of Arabic-language literature with Islamic themes - must be understood simultaneously through three elements: logic, emotion, and continuity. Applying the theory of aesthetic realism, the examination of the beauty in Maulīd Al-Diba'i cannot be separated from logic, emotion, and continuation. Logic refers to the mental process through which the poet understands the Prophet Muhammad as an individual and his struggle. Emotion, meanwhile, is involved in the poet's choice of specific words (diction) in writing the verses of the poems and voicing his love for the Prophet Muhammad. Finally, continuity is related to the existence of the text itself, from its first transmission in the town of Zabid in northern Yemen in 866 hijras (1463 CE) through the 21 st century. The text has been read and enjoyed by the Muslim world for centuries, with many of its messages practised in Muslims' everyday lives. Furthermore, using an aesthetic realism approach, the poetry collection Maulïd Al-Diba'i may be understood as an Arabic-language work of Islamic literature that conveys specific prayers, hopes, and blessings to the Prophet Muhammad. The poet desired for the text to be read as widely as possible, from generation to generation, and to guide for obtaining worldly and heavenly joy.

\section{METHOD}

The current research is descriptive that explains the crux of poetry. For this purpose the poetry collection Maulīd AlDiba' I was used and analysed. To achieve the objective analytical method was used to analyze data qualitatively. The analytical method used for this study has been selected based on the research problem, namely the dominant messages in the poetry collection Maulīd Al-Diba'i and its prayers, hopes, and blessings for the Prophet Muhammad (as well as their opposites). In poetry and prose, beauty and ugliness exist side-by-side or may exist naturally in conjunction without any deleterious effects. Chinchilla (2012) defines ugliness as all that is not beauty. As such, aesthetic realism, which argues that everything is part of a beauty phenomenon that stems from the opposition, is taken for this study. Ibn Khaldun writes that poetry and prose work through words, not ideas; in literature, ideas are secondary to words (Alami, 2011). As such, the words in Maulid Al-Diba'i are paramount in this study, as it is through them that ideals of beauty and ugliness are conveyed.

\section{RESULTS AND DISCUSSION}

Following the theory used for this study, i.e., aesthetic research, the following section examines text from the poetry collection Maulìd Al-Diba'i. It focuses on 22 lines from the fourth of the collection's eight poems. Discussion is presented in order, from the first line to the twenty-second, and focuses on the beauty and ugliness conveyed by the poet through prayers, hopes, and blessings directed at the Prophet.

Yā Nabiy, salām 'alaika, Yā Rasū l salām 'alaika يا نبي سلام عليكيا رسول سلام عليك

(1) Oh Prophet, salutations to you. Oh Messenger, salutations to you.

Yā Habīb, salām' alaika, Shalāwatullāh' alaika يا حبيب سلام عليكصلنوات الله عليك

(2) Oh, beloved (of God), salutations to you. The blessings of God upon you.

Asyraqal-badru' alainā, Fahtafat Minh al-budū ru

(3) The full moon has risen, shining upon us. The other moons have faded. 
Mitsla husnik mā ra'aynā, Qatthu Yā Wajha al-surū ri

(4) Never have we seen any moon equal to you, oh joyous face.

Anta syamsun anta badrun, Anta nū run fauqa nūri

(5 You are as the sun, you are as the moon, you are a light greater than any other.

Anta iktsīru wa ghāly, Anta mishbāhu al-sudūri

انت اكسير و غالى انت مصباح الصدور

(6) You are as a gold of great worth, you are as a lamp for all souls.

Yā Hab̄̄by, Yā Muhammad, Ya' arū sya al-khāfiqaini

ياحبيب يا حمد يا عروش الخافقين

(7) Oh beloved, oh praised Prophet, oh lovers of two joyous hearts.

Yā Mu'ayyad, Ya Mumajjad, Ya Imāma al-Qiblataini

(8) Oh Prophet, strengthened by miracles, oh imam of the two qibla.

Man rā'a wajhaka yas'ad, Yā Karīma al-walidaini

(9) Whosoever sees your face, how happy they are, oh Prophet whose parents are of glory.

Haudhuka al-shāfi al-mubarrad, Wirdunā yauma al-nusyūri

(10) Your lakes clear, air refreshing, that we will visit after the End of Days.

Ma ra'aina al-'isa hannat, Bi al-surā illa ilaika

مار راينا العيس حنت با السري الا اليك

(11) Never have we seen a white camel with black threads ringing through the night except for the camel that came to you.

Wa al-ghamāmah qad dzallat, Wa al-malā shallū'alaika

و الغمامة قد اظلت و الملا صلو ا عليك

(12) The thick clouds your parasol, and all people and beings seeking your blessings.

Wa atāka al-'ūdu yabky, Wa tadzallal baina yadaika

(13) The trees bow their branches to you and arch before you.

Wa al-tajārat Yā, Habīby, 'Indaka al-dzubyu al-nufūru

و استجارت يا حبيبى عند ك الظبي النفور

(14) Ask for salvation, oh beloved, by your side, the frightened deer running.

'Indamā syaddū all-mahāmil, Wa tanādaū li al-rahīli

(15) As a caravan prepares for departure, they call for you as they praise you.

Ji'tuhum wa al-dam' u sā'il, Qultu qif liy, yā dalīlu

جئتهم و الدمع سائل قلت قف لى يا دليل

(16) I come to them with my tears flowing, as I say: "Wait for me, oh trailblazers".

'Atuhammil liy rasā'il, Hasywuhā al-syauqu al-jazīlu

(17) Have you brought my letter, longing its contents?

اتحمل لى رسائل حشو ها الثوق الجزيل

Nahwahā tīka al-manāzil, Bil'asyiyyati wa al-bukūri

(18) To your destination so distant, night and day.

Sa '̄̀d' abdun qad tamallā, Wan-jala'anhu al-hazīnu

(19) How happy I am to find joy, and to forget all worries.

Fīka Yā Badrun tajallā, Fa laka al-washfu al-hasīnu

(20) Oh waxing moon, to you all good things.

Laisa 'azkā minka ashlan, Qatthu Yā Jaddal-Husaini

(21) Nobody is holier than you, oh Prophet, the grandfather of SayyidHusein.

Wa' alaika al-lāhu shallā Dā'iman thū la al-duhūri

(22) May God give His blessings to you, forever and for all time.

The analytical method used for this study, aesthetic realism, underscores that beauty always contains within it ugliness as an integral element. For example, while some humans prefer the afterlife, others find more joy in worldly affairs. As such, the poet reminds readers that, if they find joy in the afterlife, they should also enjoy life on earth; it is one's 
physical and spiritual worldly life that provides a bridge to the afterlife (Saleh, 2002). Siegel writes that one way to enjoy the world is to see it as involving an aesthetics of opposition. The following discussion examines the lines of Maulīd Al-Diba'i using an aesthetic realism perspective.

The first line reads: "Yâ Nabiy Salâm' Alaika, Yâ Rasûl, Salâm' Alaika/Oh Prophet, salutations to you. Oh, Messenger, salutations to you. "Through this line, the poet depicts the Prophet Muhammad as receiving the prayers of his followers, invoking peace for him in the afterlife and for Muslims on earth. Verily, the entry of the Prophet Muhammad to heaven is guaranteed; why, thus, do the faithful still pray for him? The answer is that many of the faithful have forgotten the Prophet, abandoned his example, and ignored his teachings. In the first line, the word salamis used twice by the poet; the importance of this word, which means 'peace', may be understood as a wish for the Prophet Muhammad to find love and peace, even as the social conflict occurs on earth. The Prophet's nobility and provision of charity to his followers cannot be separated from his family background. Traditionally, Prophet Muhammad is held to have been born c. 570 CE. Trusted sources of information, as well as hagiographies, depict the family background and early years of Muhammad. It is known that he came from a powerful tribe of Arabs that lived near Mecca, known as the Quraysh. Although his clan, the Banu Hashim was not powerful, it was greatly respected. Muhammad's father, Abdullah, died before Muhammad's birth; six years after Muhammad's birth, his mother Aminah died. As a result, Muhammad was given to his grandfather, Abdal-Muttalib, who died when Muhammad was eight. Afterward, he was entrusted to his uncle, the clan leader Abu Thalib (Jackson, 2006). According to Muslim tradition, as a youth Muhammad worked with the camel caravans and developed a reputation for sincerity and honesty. He ultimately caught the attention of and married Khadijah, a wealthy woman some fifteen years his elder. Until his death, Muhammad married no other woman, and Khadijah provided him with extraordinary support even in his darkest times (Feener, 2014).

The Prophet Muhammad lived an extraordinary life. At the age of forty, he received his first revelation from God. This marked a turning point in his life, and later in the lives of millions of people. The Prophet Muhammad faced significant opposition as he sought to unite the various Arab tribes into a community (ummah) united by a shared leader and faith. After his death, this new movement spread, and today more than a billion people identify themselves as Muslims and see Muhammad as a model for their lives (Jackson, 2006).

The second line reads:" Yâ Habîb Salâm' Alaika, Shalawâtul-lahu'Alaika/Oh beloved (of God), salutations to you. The blessings of God upon you. "Through this line, the poet expresses that the Prophet Muhammad is beloved by his people and that the faithful continue to pray for him. Why is the Prophet referred to as habîb (beloved)? Because he loves every one of his people, even as many people do not love him. When the faithful find themselves trapped in disagreement and enmity, the poet remembers the Prophet Muhammad and his desire to bring peace to and foster love among his people. However, as readily evidenced in society, such disagreements and enmities cannot easily be assuaged. The Prophet Muhammad was an honoured trader, who continued to preach against the gods of the unbelievers. The Prophet Muhammad despised arrogance, greed, and social irresponsibility, and thus reminded the faithful of divine judgment. The Prophet Muhammad also protected those who converted to Islam even as they were targeted by others, and urged them to find refuge in Axum, Ethiopia. As a result of such deeds, the reputation of Muhammad as a trusted prophet and servant of God rapidly spread outside of Mecca (Ruthven \& Nanji, 2004).

The third and fourth lines read: "Asyraqal-Badru 'alainâ, Fahtafat minhul-Budûru/The full moon has risen, shining upon us. The other moons have faded" and "Mitsla Husnik mâ Ra'aynâ, Qatthu Yâ Wajhas-Surûri/ Never have we seen any moon equal to you, oh joyous face". The third and fourth lines liken the Prophet Muhammad to the full moon, which rises at night to brighten the landscape. People who live in the darkness of night feel joy upon seeing the beauty of the full moon. As the moon brings light to the people, the Prophet Muhammad enlightens those whose hearts remain dark and whose minds are closed to a contemplation of God's creation. Even kings, no matter their power, could not hope to equal the greatness of the Prophet. This is particularly true if they bring suffering to their people. Oppressive kings and rulers are hated by their people, while the Prophet Muhammad is beloved by the faithful. Muhammad had a smile for everyone he met; never would he seem dour or upset to meet someone. As such, through these lines, the poet seeks to show that some people do not willingly smile at others, even those who have not wronged them.

The fifth and sixth lines read: "Anta syamsun anta badrun, Anta nûrun fauqa nûri/You are as the sun, you are as the moon, you are a light greater than any other" and /Anta iktsîru waghâly, Anta mishbâhus-sudûri/You are as the gold of great worth, you are as a lamp for all souls". In the fifth line, the poet praises the Prophet Muhammad by likening him to the sun and the full moon, as the light of lights. As such, the Prophet Muhammad is a bringer of light to a world made dark by the shirk (polytheism) of the Arabs who worshipped other gods. As such, the Prophet Muhammad sought to teach the Arabs of Mecca about the oneness of God and guide them to Islam. Monotheism is one of the central tenets of Islam, and God is seen as having no peers and no offspring. In Islam, there is no line dividing the sky and the earth; there are no interlocutors between Muslims and God (Saunders, 2002). In the sixth line, it is stated that the Prophet Muhammad is the light of lights, meaning that his teachings are passed from generation to generation without interruption. The followers of the Prophet Muhammad will untiringly continue his struggle over time. The poet feels great anxiety seeing how many Muslims have taught their peer's deviant beliefs in the name of their religion. Furthermore, many seem to lead others to crime and evil deeds. 
The seventh and eighth lines read: "Yâ Habîby, Yâ Muhammad, Ya 'arûsyal-hâfiqaini/Oh beloved, oh praised Prophet, oh lovers of two joyous hearts" and "Yâ Mu'ayyad, Ya Mumajjad, Ya Imâmal-Qiblataini/Oh Prophet, strengthened by miracles, oh imam of the two qibla". Through the seventh line, the poet expresses praise for the Prophet Muhammad, who is beloved by the faithful and who taught humanity to love and honour their families; this includes husbands and wives, two hearts united in love and beauty. Beauty is a central element, especially for women, as it shapes their identity. Generally, beauty results in visibility and captures hearts. A husband, thus, can praise his wife through his lyrics and poetry. Ugliness, meanwhile, is concealed within the marginal.

This wording is selected by the poet to convey the human tendency to separate oneself from one's family because one no longer feels love and one cannot think clearly about one's household affairs. In the eighth line, meanwhile, it is stated that the Prophet Muhammad received the miraculous Qur'an from God and was tasked with spreading its teachings around the world; at its core, Islam is a religion of dakwah or proselytism. Muslims are commanded to spread God's message around the globe and thereby transform the earth into a better and more moral place (Gordon \& Newby, 2004). The Prophet Muhammad led the faithful, both in the East and in the West, and through him, Islam influenced the world. The poet felt concerned by contemporary conditions, with cases of divorce over irreconcilable differences becoming common. Furthermore, he expressed hope that Muslims could improve their standing and equal the progress of other nations.

The ninth and tenth lines read: "Man râ'a wajhaka yas'ad, Yâ Karîmal-walidaini/Whosoever sees your face, how happy they are, oh Prophet whose parents are of glory" and "Haudhu Kash-shâfil-mubarrad, Wirdunâ yauman-nusyûri/Your lakes clear, refreshing, that we will visit after the End of Days". The ninth line conveys the poet's praise for the character of the Prophet Muhammad, who always happily greeted others and smiled at those who looked upon him. People would be happy to see him, and the Prophet Muhammad would readily help all those who came to him. Many others, however, do not compart themselves in such a manner. They may interact with persons whose behaviours are not honourable or be unwilling to help those in need. Furthermore, it is stated that both of Prophet Muhammad's parents were noble people; they were respected members of the Quraysh tribe, and while his parents were good people some of his peers were not. The poet recognized that many people would pretend to be good, even though their attitudes and behaviours were not. In the tenth line, meanwhile, it is emphasized that Heaven has lakes with clear water and refreshing air, and as such those in Heaven always enjoy God's blessings. Meanwhile, those trapped in hell would feel a great thirst and thus be jealous of those in Heaven.

Lines eleven and twelve read: "Ma ra'aina al-'isa hannat, Bi al-surā illa ilaika/Never have we seen a white camel with black threads ringing through the night except for the camel that came to you" and "Wal-ghamâmah qad dzallat, Walmalâ shallû 'alaika/The thick clouds your parasol, and all people and beings seeking your blessings". The eleventh line references the camel, a being created by Allah, had prepared itself to please the Prophet Muhammad before being ridden. The camel came to the Prophet at night, to ensure it was not seen by many people. In the twelfth line, it is stated that, for the love of the Prophet Muhammad, the clouds themselves protected him from the heat of the sun. As such, the Prophet Muhammad felt refreshed even as he rode his camel. The poet, thus, is urging those in power not to hurt, ignore, or belittle the people under them. The poet also urges readers to avoid approaching kings and rulers simply to flatter them, and to avoid becoming the slaves of their rulers.

The thirteenth and fourteenth lines read: "Wa atâkal-'ûdu yabky, Wa tadzallal baina yadaika/The trees bow their branches to you and arch before you" and "Was-tajârat Yâ, Habîby, 'Indakadz-dzubyun-nufûru/Ask for salvation, oh beloved, by your side, the frightened deer running". The thirteenth line indicates the poet's awe for the Prophet Muhammad, who - when walking in the daytime - would be protected from the sun by trees that bowed their branches in respect and arched their leaves over him. This distinguished him from the other members of the Quraysh clan, who would not receive protection from the sun. The fourteenth line, meanwhile, refers to a time when a group of deer sought to meet with the Prophet Muhammad, but ultimately ran from him as they were afraid and ashamed that they were unable to support him in his struggle to spread the teachings of Islam. In this, it may be seen that the poet recognized that many people were unhappy with the efforts of the Prophet Muhammad and his companions to spread the word of God to those Arabs who had yet to embrace Islam.

The fifteenth and sixteenth lines read: "Indamâ syaddûl-mahâmil, Wa tanâdaûlir-rahîli/As a caravan prepares for departure, they call for you as they praise you" and "Ji tuhum wad-dam'u sâ'il, Qultu qifliy, yâdalîl/I come to them with my tears flowing, as I say: 'Wait for me, oh trailblazers". The fifteenth line describes a time when the Prophet Muhammad was undertaking a day trip and passed a group of people on the road. They greeted God's beloved and praised his noble character and his love for his people. Meanwhile, when the leaders of the Quraysh tribe traveled, they would not be greeted or honoured owing to their vehement opposition to the Prophet Muhammad and his struggle. Similarly, the sixteenth line refers to a person who desired to accompany the Prophet Muhammad on his journey, and though he was late still he followed because he was certain that he would meet with the beloved and honoured leader of the faithful. In this, the poet seemingly refers to a tendency for people to not honour those who teach the truth. The Prophet Muhammad, as a man of great authority, always fought for truth and righteousness, using his personal and mental experiences in the preaching of Islam to the Arabs. These experiences included the Prophet Muhammad's 
struggles with his enemies. Truth and righteousness come from experience, and as such all authorities outside the self must be mediated through one's mental experiences (Faraouki, 2007).

The seventeenth and eighteenth lines read: “'Atuhammil liy rasā'il, Hasywuhā al-syauqu al-jazillu/Have you brought my letter, longing its contents" and "Nahwahā tīka al-manāzil, Bil'asyiyyati wa al-bukūri/To your destination so distant, night and day". The seventeenth and eighteenth lines continue to refer to the man who had been left behind by his group. These lines express this man's desire to deliver a letter to the Prophet Muhammad and express his deep longing. However, the Prophet Muhammad had already passed far in the distance, crossing a barren desert for a night and a day. From an aesthetic realism perspective, it may be understood that the poet seeks to convey that goodness and righteousness are valuable and rare things, while evil and ugliness dominate everyday life. Often, the people who should lead others by example are prone to deplorable deeds.

The nineteenth and twentieth lines read: "Sa'îd 'abdun qad tamallâ, Wan-Jala 'an hul-hazinu/How happy I am to find joy, and to forget all worries" and Fîka Yâ Badrun tajallâ, Falakal-washful-hasînu/Oh waxing moon, to you all good things". The nineteenth line indicates that the people who met the Prophet Muhammad were fortunate, as the hardships of their lives could be ameliorated. The devotion and the dignity of the Prophet Muhammad proved to be medicine for people who required his support and prayers. Using an aesthetic realism perspective, it can be understood that certain people sought to distance themselves from the Prophet Muhammad and his teachings because they considered said teachings to be detrimental to their material well-being. The twentieth line, meanwhile, refers to people who continuously prayed for the Prophet Muhammad as a noble and beloved leader, even as he was God's messenger and therefore occupied a high position in society. However, other people did not pray for the Prophet, as they believed that Muhammad did not require the prayers of his followers, or that he was even an ordinary man.

Lines twenty-one and twenty-two read: "Laisa 'azkâ Minka ashlan, Qatthu Yâ Jaddal-Husaini/Nobody is holier than you, oh Prophet, the grandfather of Sayyid Husein" and "Wa 'alaikal-lâh ushallâ Dâ' iman thûlad-duhûri/May God give His blessings to you, forever and for all time". The twenty-first line indicates that many people (aside from the Prophet Muhammad) make mistakes and commit sins, while the Prophet Muhammad was a holy man (ma'shum) who could not sin. As such, many people sought to meet with the Prophet Muhammad, either directly or indirectly. At the time, many Arabs sought to meet with the Prophet Muhammad if they had questions for him, and he would openly receive these guests. However, persons who did not have the opportunity to meet directly with the Prophet Muhammad could still read or sing the Salawat in a melodious and beautiful voice. Sayid Hussein, a grandchild of the Prophet Muhammad, is referenced by the poet because of his goodness and intelligence. Sayid Hussein was known for his good, firm, and philosophical leadership, similar to that of his father Ali Bin Thalib, who is recognized as a caliph whose broad knowledge was referenced and recorded by later scholars. Any type of recorded knowledge becomes embedded in the human soul. Pens, like writing utensils, are spiritual as spirit and reality are united within them (Whittingham, 2007). However, Sayid Hussein had a short life; he was sadistically killed by Yazid II, the son of Mu'awiyah bin Abi Sufyan because Yazid feared that Sayid Hussein had inherited his grandfather's role as the leader of Islam. In the twenty-second line, the poet prays that God will love and care for the Prophet Muhammad until the end of days. However, in reality, many people do not pray for the Prophet Muhammad (through Salawat or otherwise) because they do not love him.

\section{CONCLUSION}

Based on the discussion and analysis above, it may be concluded that the poetry collection Maulīd Al-Diba ' $i$ is a work of Arabic-language Islamic literature that was influenced by the verses of the Qur'an and their beauty. The verses of Maulid Al-Diba'i are conveyed through the language of prayers, hopes, and blessings. These prayers, hopes, and blessings contain within them their beauty, both at the surface and below it. The poet, Abdurrahman Al-Diba'i, readily conveys his prayers, hopes, and blessings by briefly retelling the story of the Prophet Muhammad's travels to spread Islam throughout the Arabian Peninsula.

From an aesthetic realism perspective, it may be seen that behind the beauty of the verses the poet implicitly conveyed the opposite: the ugliness that hides behind prayers, hopes, and blessings. Prayers (beauty) are opposed to silence (ugliness), understood as the refusal to ask God and the Prophet Muhammad for anything. Hopes (beauty) are opposed to desperation (ugliness); people may readily give into desperation when they face difficult problems or must overcome obstacles. Finally, blessings (beauty) are opposed to insults (ugliness), as many have forgotten or distanced themselves from the teachings of the Prophet Muhammad. Such ugliness is conveyed implicitly through the verses of Maulid AlDiba' $i$, which reflect the social facts of contemporary Arab society.

\section{LIMITATION AND STUDY FORWARD}

The study has a few limitations. Firstly, they only explain the specific features of poetry. Secondly, only the poetry of one poet was analysed. The sturdy forward can compare the aspects of multiple poets or considered more dimensions. For this study, however, Maulïd Al-Diba'I is not discussed in terms of melody (rhyme and rhythm); such research would require extensive field studies in pesantren that utilize the text and give it a voice in varied ways. 


\section{ACKNOWLEDGMENT}

The authors confirmed that there is no conflict of interest in this article. Also, no financial support is received for conducting this research.

\section{AUTHORS CONTRIBUTION}

Fadlil Munawwar Manshur is the main researcher. He solely contributes to generating research ideas, writing the proposal, and presenting research results, and finalizing the whole study.

\section{REFERENCES}

1. Alahoul, M. H. M., Azizan, N., \& Alwi, N. H. (2016). Factors that affect the use of Malaysian e-learning websites by visually impaired users in the transfer of Islamic knowledge. Journal of Advanced Research in Social Sciences and Humanities, 1(1), 30-40. https://doi.org/10.26500/JARSSH-01-2016-0104

2. Alami, M. H. (2011). Art and architecture in the Islamic tradition aesthetics, politics and desire in early Islam. New York, NY: Palgrave Macmillan. https://doi.org/10.5040/9780755694471

3. Ali, W. (1997). Modern Islamic Art: Development and continuity. Florida, FL: University Press of Florida.

4. Ali, W. (2002). Breaking the Veils: Women Artists from the Islamic world. Jordan, Amman: Royal Society of Fine Arts.

5. Balushi, H. S. A. A., Bulushi, N. A. A. A., and Al-Riyami, R. J. M. (2018). The alt metrics for measuring readers intentions towards scholarly contents in the field of information security. Journal of Advanced Research in Social Sciences and Humanities, 3(1), 23-30. https://doi.org/10.26500/JARSSH-03-2018-0103

6. Barlas, A. (2002). Believing women in Islam unreading patriarchal interpretations of the Qur'ān, Austin, TX: University of Texas Press.

7. Barlas, A. (2008). Re-understanding Islam: A Double Critique. AA Assen, Netherlands: Van Gorcum.

8. Bin Tyeer, S. R. (2016). The Qur'an and the Aesthetics of Premodern Arabic Prose. New York, NY: Springer. https://doi.org/10.1057/978-1-137-59875-2

9. Brink, C. O. (2011). Horace on Poetry: Epistles book II: The letters to Augustus and Florus. Cambridge, UK: Cambridge University Press.

10. Chinchilla, O. D. (2012). Towards a better understanding of the ugly in literature. Revista de Lenguas Modernas, 17, 1-22.

11. Citraningtyas, C. E. (2017). Readers responses on Indonesian folktales: A proposal for folktale reconstruction. International Journal of Humanities, Arts and Social Sciences, 3(5), 197-203. https://doi.org/10.20469/ijhss.3.20002-5

12. Faraouki, S.-T. (2007). Beshara and Ibn 'Arabi, a movement of Sufi spirituality in the modern world. Oxford, UK: Anqa Publishing.

13. Feener, M. R. (2014). Islam in world cultures, comparative perspectives. Oxford, UK: ABC Clio.

14. Ghehi, H. B. (2017). Aesthetic and concept of beauty in the Quran. International Journal of Arts, 7(1).

15. Goldschmidt Jr, A. \& Davidson, L. (2006). A concise history of the Middle East. Oxford, UK: Westview Press.

16. Gomez, K., \& Gomez, L. M. (2018). Meeting in the middle: The challenge and promise of supporting stem learning through Language and literacy infusion. Journal of Advances in Humanities and Social Sciences, 4(6), 258-266. https://doi.org/10.20474/jahss-4.6.3

17. Gonzalez, V. (2001). Beauty and Islam, aesthetic in Islamic art and architecture. London, UK: I.B, Tauris Publisher. https://doi.org/10.5040/9780755699353

18. Gordon, D. \& Newby, (2004). A concise encyclopedia of Islam. Oxford, UK: Oneworld Publications.

19. Groff, P. S. \& Leaman, O. (2007). Islamic Philosophy A-Z. Edinburgh, Scotland: Edinburgh University.

20. Hegel, G. W. F. (1998). Aesthetics. Gloucestershire, Clarendon Press.

21. Jackson, R. (2006). Fifty key figures In Islam. London, UK: Routledge. https://doi.org/10.4324/9780203001387

22. Kartika, D. S. \& Perwira, N. G. (2004). Introduction to Aesthetics. Bandung, Indonesia: Rekayasa Sains.

23. O'Mahony, C. T. (2018). An analysis of dialects and how they are neither linguistically superior nor inferior to one another. International Journal of Humanities, Arts and Social Sciences, 4(5), 221-226. https://doi.org/10.20469/ijhss.4.10004-5

24. Pal, A. (2011). 'Islam' means peace, understanding the Muslim principle of nonviolence today. Oxford, UK: Praeger.

25. Perey, A. (1976). The aesthetic realism of Eli Siegel as a teaching method in anthropology. Council on Anthropology and Education Quarterly, 7(4), 46-48. https://doi.org/10.1525/aeq.1976.7.4.05x1663y

26. Ruthven, M. \& Nanji, A. (2004). Historical atlas of the Islamic world. Harvard, CA: Harvard University Press.

27. Saleh, M. I. (2002). A dictionary of Islamic words and expression, Arabic-English with an Arabic index. AlJumu'ah Magazine.

28. Saunders, J. J. (2002). A history of medieval Islam. London, UK: Routledge. https://doi.org/10.4324/9780203199763

29. Siegel, E. (1981). Self and world, an explanation of aesthetic realism. New York, NY: Definition Press. 
Humanities \& Social Sciences Reviews elSSN: 2395-6518, Vol 8, No 3, 2020, pp 890-899 https://doi.org/10.18510/hssr.2020.8393

30. Siegel, E. (1997). The modern quarterly beginnings of aesthetic realism, 1922-1923, New York, NY: Definition Press.

31. Slethaug, G. E. (2007). Beautiful chaos, theory and metachaotics in recent American fiction. New York, NY: State University of New York Press.

32. Susanto, D. (2015). Dictionary of literary terms. Yogyakarta, Indonesia: Pustaka Pelajar.

33. Syafiie, I. K. (1998). Islamic logic, ethics and aesthetics. Jakarta, Indonesia: P.T. Pertja.

34. Whittingham, M. (2007). Al-Ghazali and the Qur'an, one book, many meanings. London, UK: Routledge. https://doi.org/10.4324/9780203964651 